\title{
POTENTIAL FACTORS LIMITING BROWN TROUT CATCHES BY ANGLERS - A CASE STUDY
}

\author{
Tomáš Zapletal1, Luděk Šlapanský², Jan Grmela ${ }^{3}$ \\ ${ }^{1}$ Faculty of International Relations, Prague University of Economics and Business, W. Churchill sq. 1938/4, 13067 \\ Prague, Czech Republic \\ 2 Institute of Vertebrate Biology, Brno, Květná 8, 60365 Brno, Czech Republic \\ ${ }^{3}$ Department of Zoology, Fishery, Hydrobiology and Apiculture, Faculty of AgriSciences, Mendel University \\ in Brno, Zemědělská 1, 61300 Brno, Czech Republic
}

Link to this article: https://doi.org/10.11118/actaun.2021.031

Received: 24. 3. 2021, Accepted: 26. 4. 2021

To cite this article: ZAPLETAL TOMÁŠ, ŠLAPANSKÝ LUDĚK, GRMELA JAN. 2021. Potential Factors Limiting Brown Trout Catches by Anglers - A Case Study. Acta Universitatis Agriculturae et Silviculturae Mendelianae Brunensis, 69(3): 337-343.

\begin{abstract}
In recent years, the numbers of native brown trout caught by anglers has declined throughout the Czech Republic. In this study, we focus on individual factors potentially related to this negative trend, based primarily on long-term angling catch data (2000-2020) for twenty fishing grounds of the Czech and Moravian angling unions covering twelve upland trout streams. The results indicate that angling pressure, expressed as annual number of attendances, is the most important factor in the decline of trout populations, with drought caused by climate change as a secondary factor. There is a clear need for changes in current fisheries management practice, using new sustainable development scenarios, in order to protect and improve unfavourable conditions for natural brown trout populations.
\end{abstract}

Keywords: Salmo trutta, angling pressure, drought, scenarios

\section{INTRODUCTION}

Brown trout (Salmo trutta L.), a typical autochthonic fish species of stream waters, is both an important indicator of ecosystem quality and a popular target of recreational fisheries (Kottelat and Freyhof, 2007). Unfortunately, brown trout populations have shown a declining trend over many areas of its original European distribution area, the main causes being changes in the species' functional habitat, such as reduced flows due to prolonged drought brought on by climate change (Hari et al., 2006), or stream disturbances caused by improper and unauthorised water management (Baskaya et al., 2011) and habitat degradation (Roni et al., 2011). In some isolated cases, trout declines have been caused by disease outbreaks (Waldner et al., 2020) or, potentially, overpredation (Krpo-Ćetković et al., 2019).
In the Czech Republic, a decrease over time in the brown trout catch by anglers has been detected based on annual evaluations of reported catches by the Czech Anglers Union (CAU) and Moravian Anglers Union (MAU). A number of factors have been put forward as contributing to this decline, including management of small hydropower plants (Kubečka et al., 1997) and predation (Spurný, 2020); however, the main factor is thought to be current management of fishing grounds, particularly as regards stocking with hatchery-reared trout, both as an explanation for the decline in catches and as a threat to native brown trout populations (Randák, 2020). In some fishing grounds, hatchery-reared trout are heavily stocked and make up a large proportion of the total catch, despite studies in Austria confirming that such fish interbreed with native fish, with negative impacts on their survival (Pinter el al., 2012), and evidence of direct 
competition for shelter and food resources in Czech fishing grounds (Zapletal and Špaček, 2018). Generally speaking, angling pressure tends to be mentioned far less frequently when assessing possible threats, despite the important role it could play in brown trout population dynamics and its subsequent impact on total catch.

Clearly, there is a need for a re-evaluation of the current situation in the Czech Republic aimed at identifying sustainable development models for future recreational fishing. Here, we analyse 20 years of angling catch data to assess (1) possible factors for the decrease in brown trout catches in selected fishing grounds, and (2) the degree to which the declining brown trout catch is connected angling activity.

\section{MATERIALS AND METHODS}

\section{Study Sites}

This study took place on 12 salmonid rivers and streams located in east Bohemia and south Moravia (Czech Republic), all of which fall within the Elbe and Danube drainage basins (Fig. 1). All 12 rivers are generally characterised by runs and riffles with coarse substrate alternating with deeper pools, and can be considered as typical trout streams for the
Czech Republic. For the purposes of this study, each fishing ground was separated into three categories (Tab. I), i.e. brooks (average inflow $<3.0 \mathrm{~m}^{3}$ ), middle rivers (min. inflow 3.0-5.0 $\mathrm{m}^{3}$ ) and rivers (min. inflow $>5.0 \mathrm{~m}^{3}$ ). Average length of weir reservoir volume was $600 \mathrm{~m}$, average weir height $1.3 \mathrm{~m}$ and average depth of weir reservoir $0.5 \mathrm{~m}$. Twenty-two percent of these weirs were built after 1990.

Located along the 12 rivers are 20 fishing grounds, each having their own provisions based on CAU and MAU rules (Tab. I). These grounds are regularly stocked with brown trout, along with other salmonid species such as rainbow trout (Oncorhynchus mykiss Walbaum), brook trout (Salvelinus fontinalis Mitchill) and European grayling (Thymallus thymallus L.), based on individual stocking plans established separately for each ground, which in turn are based on the previous year's catch results.

\section{Data Analysis}

Trout angling catch data covering the period 2000-2020 were obtained from CAU and MAU. Based on the data provided, we evaluated the average number of trout caught, the number of anglers using each fishing ground, the annual number of trout per angler per hectare (ha) and influence of the minimum legal length limit.

I: List of fishing grounds evaluated in this study, with river categorisation, inflow range (min-max) and average inflow; *natural habitat, ${ }^{* *}$ partly artificial zone, ${ }^{* * *}$ totally artificial zone

\begin{tabular}{lcccc}
\hline \multicolumn{1}{c}{ Ground } & Watercourse & Category & $Q_{\text {range }}$ & $Q_{\text {average }}$ \\
\hline Bělá 3** & Bělá & Brook & $0.1-4.4$ & 0.5 \\
Čistá 1* & Čistá & Brook & $0.5-11.7$ & 1.2 \\
\hline Doubrava 5P** & Doubrava & Brook & $0.3-3.4$ & 2.8 \\
Jihlava 5A** & Jihlava & River & $1.7-43.1$ & 5.5 \\
Jihlava 5B** & Jihlava & River & $1.6-40.2$ & 5.2 \\
Jihlava 5C** & Jihlava & River & $1.5-38.5$ & 5.1 \\
Labe 38** & Labe & River & $1.4-55.8$ & 10.3 \\
Metuje 4*** & Metuje & River & $1.4-38.4$ & 8.6 \\
Oslava 6** & Oslava & Middle River & $0.6-66.0$ & 4.1 \\
Svitava 2*** & Svitava & Midver & $1.3-37.0$ & 7.0 \\
Svitava 3** & Svitava & Middle River & $0.9-27.9$ & 4.9 \\
Svitava 4** & Svitava & Brook & $0.6-14.5$ & 3.8 \\
Svitava 5** & Svitava & River & $2.4-4.7$ & 1.2 \\
Svratka 7-8** & Svratka & River & $1.8-42.8$ & 8.2 \\
Svratka 9-10** & Svratka & River & $0.6-39.2$ & 8.0 \\
Svratka 12* & Svratka & Brook & $0.3-17.7$ & 7.8 \\
Svratka 14* & Svratka & Middle River & $0.9-43.9$ & 1.3 \\
Tichá Orlice 3*** & Tichá Orlice & Brook & $0.6-26.7$ & 4.8 \\
Úpa 3*** & Úpa & Brook & $0.3-18.6$ & 2.2 \\
Zdobnice 1* & Zdobnice & & 1.5 \\
\hline
\end{tabular}




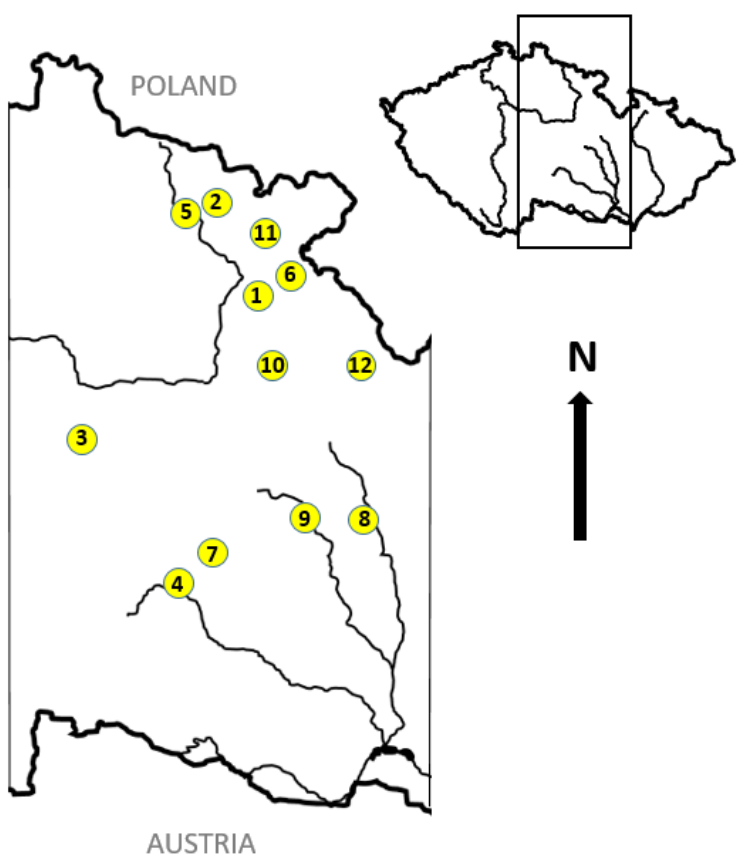

1: Location of the 12 rivers examined in this study. 1 = Bèlá, 2 = Cistá, 3 = Doubrava, 4 = Jihlava, 5 = Labe (Elbe), $6=$ Metuje, $7=$ Oslava, $8=$ Svitava, $9=$ Svratka, $10=$ Tichá Orlice, 11 = Úpa, $12=$ Zdobnice.

Quantitative analysis of the different variables, including information on important factors affecting the brown trout catch (evaluated factors), was performed using correlation (partial coefficient only), generalised linear models (GLM; Fox, 2003) and principal component analysis, using the $\mathrm{R}$ core programme (Crawley, 2007).

Periods of drought were based on the number of days with inflow $<\mathrm{Q}_{355}$ (water present 355 days annually) over the period 2000-2020, the data being sourced from the Elbe and Morava River Boards. The drought data were categorised based on a five-point scale (see Tab. II), where $1=$ no inflow, separated pools only, and $5=$ full $Q_{355}$. Water quality (WQ) was based on biochemical oxygen demand (BOD) and chemical oxygen demand (COD) and assessed using the Gini index (Zapletal, 2020).

The number of Eurasian otters (Lutra lutra L.) at each locality was estimated based on personal experience in dealing with reports of 'damage' caused by specially protected animals. Potential impacts from other important trout predators (e.g. cormorants (Phalacrocorax carbo L.) and herons (Ardea cinerea L.)) were ignored as available information on numbers were inconsistent.
Presence/absence data were obtained from the official quadrat mapping network (Czech Nature Conservation Agency, 2020) and from personal field observations and reports from the public.

Habitat fragmentation within each fishing ground was based on the number of migration barriers with no fish pass per km (MIG; includes small hydropower plants), the data being sourced from the Elbe and Morava River Boards. The MIG data was then categorised based on two five-point scales (see Tab. II), (1) river fragmentation scale, where 1 = no migration barriers and 5 = highly fragmented, where a barrier without a fish pass regularly occurs within $500 \mathrm{~m}$, and (2) degree of fragmentation, where 1 = barrier without fish pass occurs every 0 to $2 \mathrm{~km}$ and 5 = barriers occur every 8 to $10 \mathrm{~km}$.

\section{RESULTS AND DISCUSSION}

\section{Factors Affecting Brown Trout Presence}

Data for both CAU and MAU rivers indicated a steep decline in brown trout caught between 2000 and 2010, with numbers caught for the following 10 years remaining relatively stable (Figs. 2, 3). The most significant factors affecting the brown trout catches were angling pressure, expressed as trout caught per number of attendances per ha, and water quality (both $P<0.01$; Fig. 4, Tab. III), with water quality affecting all stream categories equally and angling pressure of increasing importance in smaller river categories ('brooks'; Fig. 5). The second most important factor affecting the catch was drought $(P<0.05$; Tab. III), with larger rivers and smaller brooks affected equally (Fig. 5), followed by presence of otters, though this was only significant $(P=0.05$; Tab. III) and affected all rivers equally (Fig. 5). Perhaps surprisingly, the influence of MIGs proved not to have any significant effect on brown trout catch (Tab. III).

Our data showed that stream water quality, particularly as regards organic pollution, improved gradually over the 2000-2020 monitoring period, which is consistent with previously published data (Zapletal, 2020). As such, water quality can be seen as a significant positive factor influencing the trout catch in all river categories, with positive impacts on trout survival and spawning. However, reduced organic pollution (mainly from point sources) also reduced the food base for macroinvertebrates, resulting in localised decreases in density and biomass that could also have had a negative impact on the trout population (Friberg et al., 2010).

II: Five point scale of drought and MIG assessment

\begin{tabular}{lccccc}
\hline \multicolumn{1}{c}{ Scale number } & 1 & 2 & 3 & 4 & 5 \\
\hline Drought & no inflow & connected pools & medial inflow & standard inflow & full inflow \\
Barrier distribution & $0-2 \mathrm{~km}$ & $2-4 \mathrm{~km}$ & $4-6 \mathrm{~km}$ & $6-8 \mathrm{~km}$ & $8-10 \mathrm{~km}$ \\
Fragmentation & no barriers & lower occurrence & medial fragmented higher occurrence highly fragmented \\
\hline
\end{tabular}


On the other hand, the highly significant negative impact of angling pressure on the brown trout catch concurs with studies from other countries (e.g. Ayllón et al., 2018), where an increasing demand for fishing permits has been implicated. In this study we only worked with data on brown trout harvest rate; however, it must also be considered that, in addition to the direct effect of removing adult fish, thereby limiting natural reproduction, indirect effects from fisheries management, such as stocking streams with unsuitable, genetically unrelated, fish stocks (e.g. see Fleming and Petersson, 2001; Kohout et al., 2012) or non-native fish species, such as rainbow trout and brook trout (see Fausch, 2007), will also have had an important impact. Further, the fish used to stock wild populations are obtained from fish farms, and consequently are poorly adapted to natural conditions (Pinter et al., 2019). Despite this, fisheries management is generally perceived as a significant strength in the conservation of brown trout and other aquatic organisms by the angling public, alongside improved water quality and river revitalisation. In addition, high angling pressure has an important influence on the survival of sub-adult brown trout into adulthood, i.e. many trout may die soon after being released back into the river, due to repeated catching over a short period of time and/ or bad or poor handling.

Drought was also a significant factor $(P<0.05)$ negatively influencing the brown trout catch in this study, and this will be primarily reflected in temporary or permanent direct impacts, such as reduced (or absent) water levels affecting habitat availability, as well as indirect impacts such as reductions in oxygen levels, food availability, spawning success and water quality (e.g. see Isaak et al., 2018).

Following a sharp decline in the European population since the 1980s, otter numbers have increased once again in the study area and otter

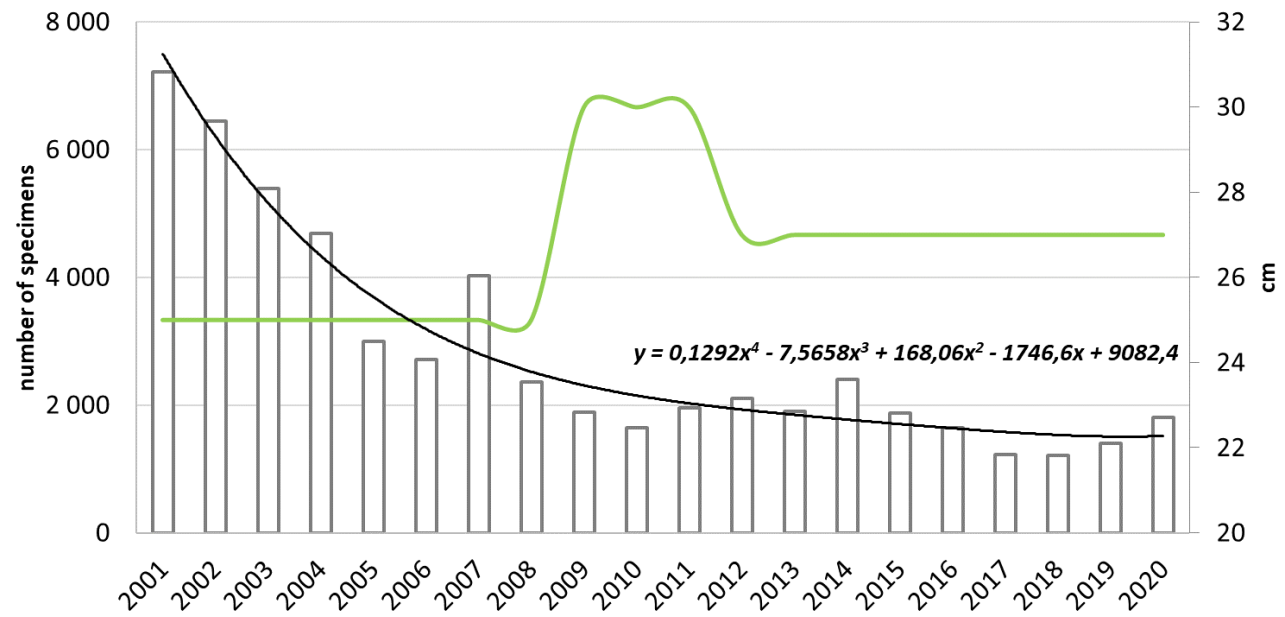

2: Development of brown trout catch at CAU fishing grounds for the period 2000-2020. Also shown is the influence of minimum length limit (bold green line).

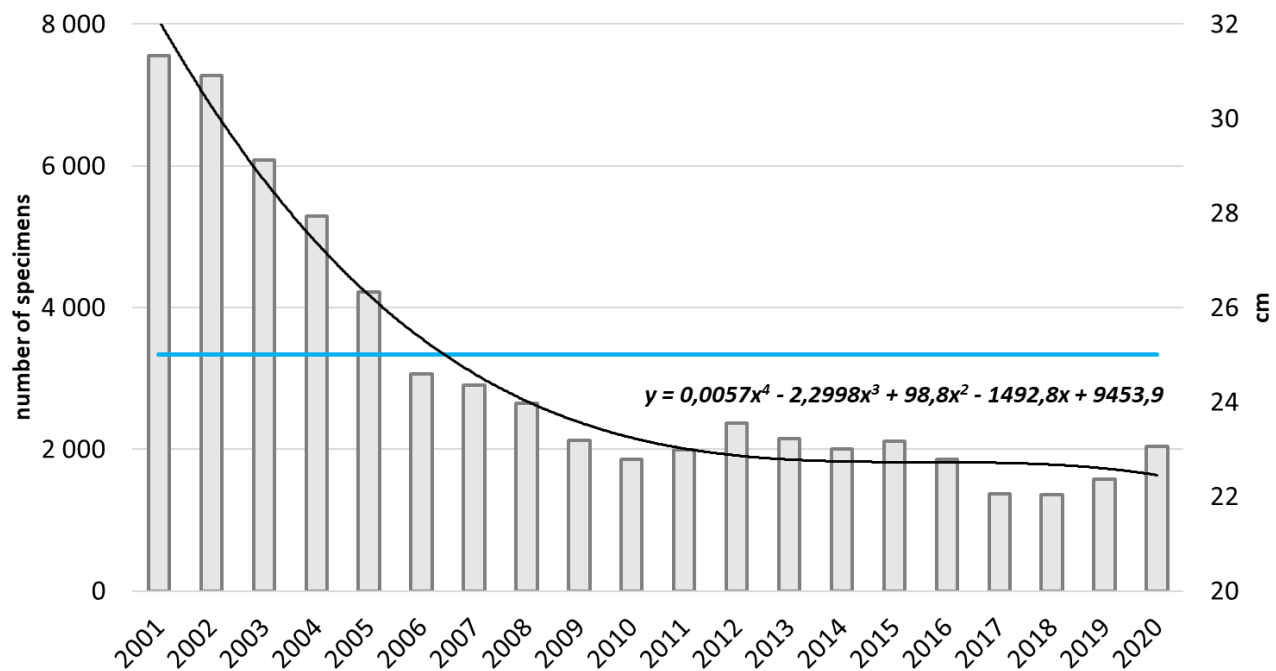

3: Development of brown trout catch at MAU fishing grounds for the period 2000-2020. Also shown is the influence of minimum length limit (bold blue line). 


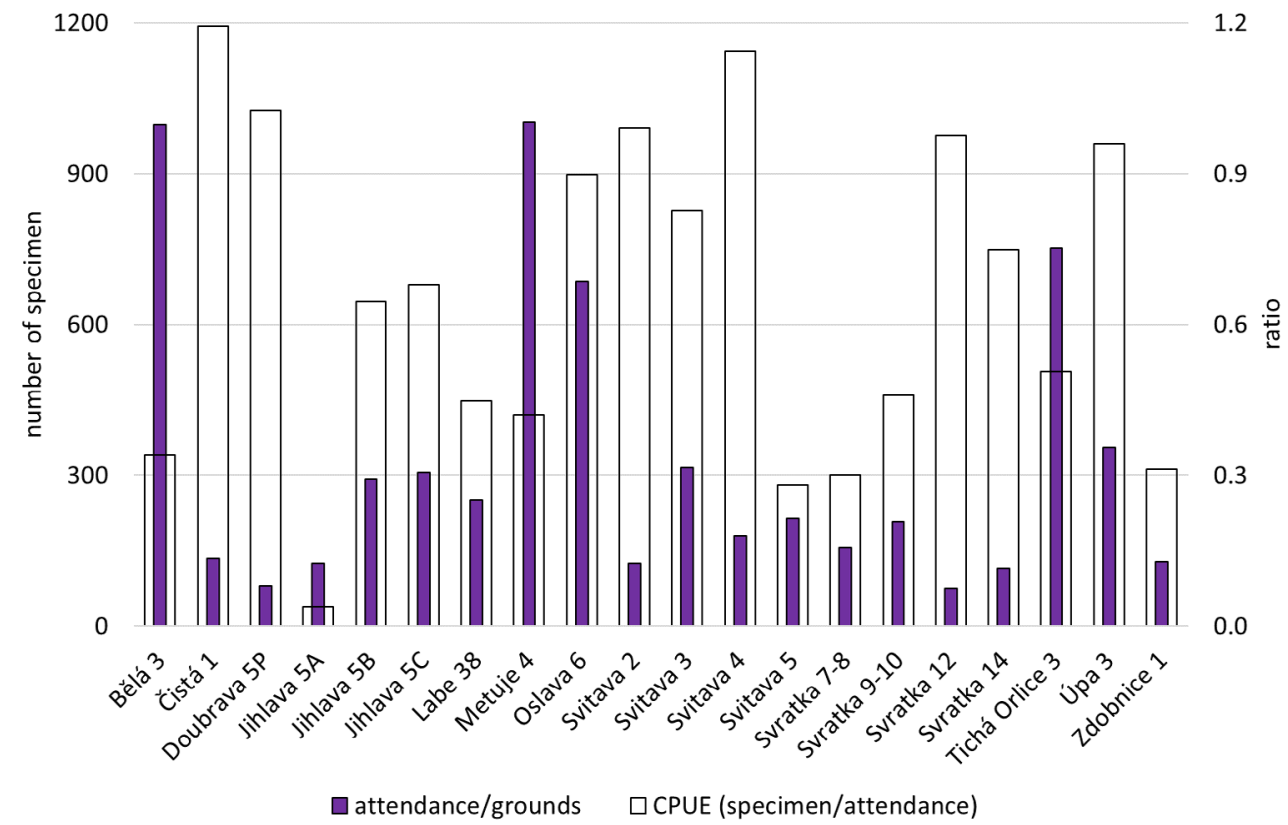

4: Average catch per unit effort (CPUE) for the period 2000-2020, expressed as number of brown trout caught per attendance

III: Correlation and regression values (partial correlation index, $R$ square and $P$ value) for trout biomass $\times$ other factors (angling pressure, drought, water quality (WQ), influence of predators, migration barriers (MIG)

\begin{tabular}{lrcccc}
\hline & Pressure & Drought & WQ & Predators & MIG \\
\hline$\rho$ & $-0.74^{* *}$ & $-0.31^{*}$ & $0.64^{* *}$ & $-0.28^{*}$ & 0.20 \\
$R^{2}$ & $0.28^{* *}$ & $0.31^{* *}$ & $0.41^{* *}$ & $0.27^{*}$ & 0.18 \\
$P$ & $<0.01^{* *}$ & $0.03^{*}$ & $<0.01^{* *}$ & $0.05^{*}$ & 0.18 \\
\hline
\end{tabular}

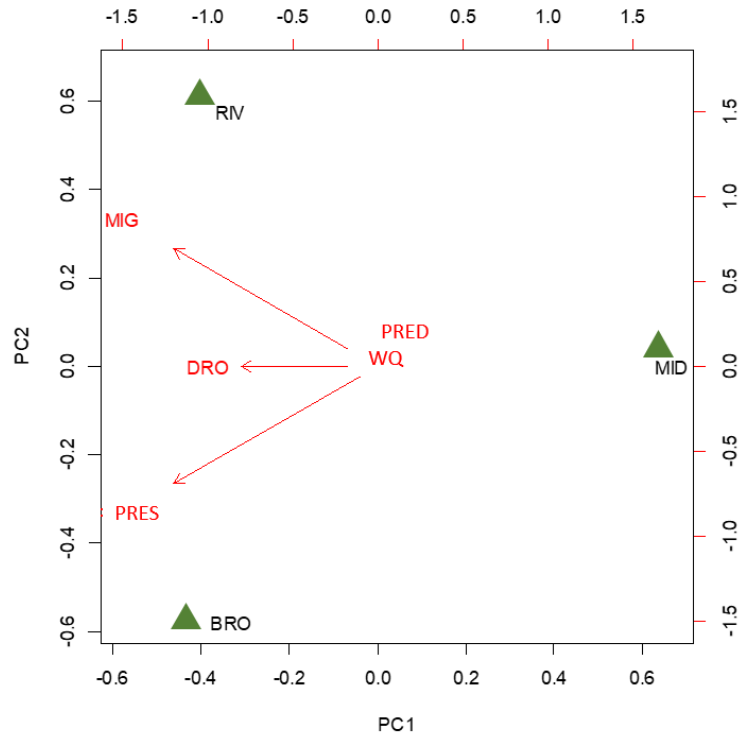

5: Principal component analysis for the main factors affecting brown trout presence $(B R O=$ brooks, $M I D=$ middle rivers, $R I V=$ rivers, $P R E S=$ angling pressure, $P R E D=$ influence of predators, $M I G=$ migration barriers, $W Q=$ water quality $D R O=$ drought signs (sightings, tracks and faecal remains) are now found at all sites. Since 2010, numbers appear to have remained stable, suggesting that the population has reached carrying capacity in the study area. While the data suggested that otter numbers may be higher at larger river sites, presumably as the food base is higher, the PCA results suggest that otter presence is of similar importance as regards the trout catch for all river categories (Fig. 5). Furthermore, otter presence was barely significant as a factor affecting the trout catch $(P=0.05$; Tab. III). Despite our data showing no recent rise in otter numbers and a limited impact on the catch, anglers mistakenly perceive otter numbers as constantly increasing (Krpo-Ćetković et al., 2019; Spurný, 2020). Furthermore, articles in fisheries magazines tend to be full of reports that the situation in trout streams is becoming untenable (e.g. Spurný, 2020). Such pressure has led the Austrian government, for example, to allow 'limited' control of otter numbers, despite its protected status, in an attempt to prevent disruption of fish stocks, this despite the fact that studies have repeatedly shown that otters can coexist with trout populations in natural streams (Jacobsen, 2005; Kottelat and Freyhof, 2007). This may be less true in anthropogenically modified lowland streams, however, where trout lack the cover and habitat complexity to avoid predation. In such areas, other predators, such as piscivorous birds (great cormorant, grey heron), can remove large numbers of fish from both stocked and natural fisheries (Harris et al., 2008).

Since the turn of the $20^{\text {th }}$ century, river regulation and construction of MIGs and SHPs, often with non-functional fish passages, has been implicated in reducing wild trout stocks by fragmenting 
the river network and preventing migration to spawning grounds (Atkinson et al., 2020). In our study area, watercourses are primarily affected by hydropeaking SHPs that allow passage of water trough derivation channels (Baskaya et al., 2011). Despite this, MIGs had a non-significant impact on the brown trout catch ( $P>0.05$, Tab. III). Though MIGs appeared to have a greater effect on larger rivers (Fig. 5), this is almost certainly due to the higher number of MIGs on such rivers.

\section{Possible Scenarios for Future Protection of Brown Trout Populations}

In light of our results, three possible scenarios for a sustainable development (Tufts et al., 2015) of trout fisheries management can be envisioned. The first scenario comprises the so-called zero variant, i.e. leaving trout fisheries management in the Czech Republic as it is. Based on the results outlined above, however, this would not appear to be a sustainable option. The second scenario is based on a previously proposed and enacted reorganisation of Czech trout fishing, which involves strengthening native trout and grayling populations, increasing the proportion of protected trout areas and only occasionally stocking rainbow trout and grayling while disturbing the natural gene pool of native fish as little as possible. The third scenario is based on the perception that otter predation has caused undue pressure on trout fisheries, and suggests that the proportion of protected sections should not increase, but that native fish species should be intensively reared and stocked and that a strong lobbyist should create pressure at the government level to legally reduce fish predators (particularly otters) along angling stretches.

While interpretation of possible scenarios has triggered a stormy debate amongst interested parties, it is clear that some form of state intervention regarding present legislation is needed in order to reach a socially acceptable compromise (Zapletal, 2020). For example, Spurný (2020) is of the opinion that previous procedures are not necessarily meaningless and leans toward the third scenario based on heavy stocking and controlled regulation of fish predators. In contrast, Randák (2020) is a strong proponent of the second variant, which is closer to changes already being implemented. A compromise solution might include artificial farming of native fish species and only stocking where the gene pool has already been disturbed. Non-native fish species such as rainbow trout, which do not cross with brown trout and show reduced competition for food, could be stocked episodically. Furthermore, Jurajda et al. (2020) recommend that no stocking should take place in selected mountain stretches where genetically pure fish stocks are still preserved.

\section{CONCLUSION}

The brown trout catch in at our study localities was negatively influenced by two factors, angling pressure and drought, though improved organic water quality has had a positive effect over the same period. Others factors, such as presence of fish predators (otters) or migration barriers (weirs) that resulted in fragmentation of the flow continuum were either marginally significant $(P=0.05)$ or not significant. The main challenge for the future must be to reduce pressure on fish stock and promote natural native fish populations as much as possible, while providing limited stocking of non-native salmonid species where there is no other option. Nevertheless, there is a clear need to restructure trout fishing in the Czech Republic, hand in hand with diversification and stream revitalisation.

\section{Acknowledgements}

This research was financially supported through Project [No. F/2/15/2019] - Economy and Politics of Salmonid Angling from the Faculty of International Relations, Prague University of Economics and Business. We would like to thank Dr. Kevin Roche for help with English language correction.

\section{REFERENCES}

ATKINSON, S., BRUEN, M., SUllivan, J. J., TURNER, J. N., BALL, B., CARlSSON, J., BUllOCK, C., CASSERLY, C. M. and KELLY-QUINN, M. 2020. An inspection-based assessment of obstacles to salmon, trout, eel and lamprey migration and river channel connectivity in Ireland. Science of the Total Environment, 719(1): 1-13.

AYLLÓN, D., RAILSBACK, S. F., ALMODÓVAR, A., NICOLA, G. G., VINCENZI, S., ELVIRA, B. and GRIMM, V. 2018. Eco-evolutionary responses to recreational fishing under different harvest regulations. Ecology and Evolution, 8(1): 9600-9613.

BASKAYA, S., BASKAYA, E. and SARI, A. 2011. The principal negative environmental impacts of small hydropower plants in Turkey. African Journal of Agricultural Research, 6(14): 3284-3290.

CZECH NATURE CONSERVATION AGENCY. 2020. Otter quadrat mapping network. [Online]. Available at: https://data.nature.cz/ds/19 [Accessed: 2020, December 20]. 
CRAWLEY, M. J. 2007. The R book. $1^{\text {st }}$ Edition. Hamilton: McMasters University.

FAUSCH, K. D. 2007. Introduction, establishment and effects of nonnative salmonids: considering the risk of rainbow trout invasion in the United Kingdom. Journal of Fish Biology, 71(Suppl. D): 1-32.

FLEMING, I. A. and PETERSSON, E. 2001. The ability of released hatchery salmonids to breed and contribute to the natural productivity of wild populations. Nordic Journal of Freshwater Research, 75(1): 71-98.

FOX, J. 2003. Effect displays in $R$ for Generalised linear model. $1^{\text {st }}$ Edition. Wiley Chichester.

FRIBERG, N., SKRIVER, J., LARSEN, S. E., PEDERSEN, M. L. and BUFFAGNI, A. 2010. Stream macroinvertebrate occurrence along gradients in organic pollution and eutrophication. Freshwater Biology, 55(7): 1405-1419.

HARI, R. E., LIVINGSTONE, D. M., SIBER, R., BURKHARDT-HOLM, P. and GÜTINGER, H. 2006. Consequences of climatic change for water temperature and brown trout populations in Alpine rivers and streams. Global Change Ecology, 12(1): 10-26.

HARRIS, C. M., CALLADINE, J. R., WERNHAM, C. V. and PARK, K. J. 2008. Impacts of piscivorous birds on salmonid populations and game fisheries in Scotland: a review. Wildlife Biology, 14(1): 395-411.

ISAAK, D. J., LUCE, C., HORAN, D. L., CHANDLER, G. L., WOLLRAB, S. P. and NAGEL, D. E. 2018. Global Warming of Salmon and Trout Rivers in the Northwestern US: Road to Ruin or Path Through Purgatory? Transactions of the American Fisheries Society, 147(3): 566-587.

JURAJDA, P., BEDNAŘ́í, A., BARTÁKOVÁ, V., MENDEL, J., JURAJDOVÁ, Z. and MIKL, L. 2020. Unique trout population in the Giant Mountains [in Czech: Unikátní populace pstruha obecného v Krkonoších]. Rybářství, 5: 54-55.

KOHOUT, J., KAŠKOVÁ, I., PAPOUŠEK, I., ŠEDIVÁ, A. and ŠLECHTA, V. 2012. Effects of stocking on the genetic structure of brown trout, Salmo trutta, in Central Europe inferred from mitochondrial and nuclear DNA markers. Fisheries Management and Ecology, 19(1): 252-263.

KRPO-ĆETKOVIĆ, J., SUBOTIĆ, S., SKORIĆ, S. and ĆIROVIĆ, D. 2019. Diet of the Eurasian otter (Lutra lutra) on the River Gradac, Serbia: Predation in a brown trout-dominated stream. Aquatic Conservation, 29(2): 282-291.

KOTTELAT, M. and FREYHOF, J. 2007. Handbook of European Freshwater Fishes. $1^{\text {st }}$ Edition. Berlin: Publication Kottelat.

KUBEČKA, J., MATĚNA, J. and HARTVICH, P. 1997. Adverse ecological effects of small hydropower stations in the Czech Republic. River Research and Applications, 13(2): 101-113.

PINTER, K., EPIFANIO, J. and UNFER, G. 2019. Release of hatchery-reared brown trout (Salmo trutta) as threat to wild population? A case study from Austria. Fisheries Research, 219(1): 456-476.

RANDÁK, T. 2020. Perspectives of fishery management in trout waters [in Czech: Perspektivy rybářského hospodaření ve pstruhových vodách]. Rybářství, 3: 36-39.

RONI, P., HANSON, K. and BEECHIE, T. 2011. Global Review of the Physical and Biological Effectiveness of Stream Habitat Rehabilitation Techniques. North American Journal of Fisheries Management, 28(3): 856-890.

SPURNÝ, P. 2020. Conditions in trout waters are deteriorating faster than we expected [in Czech: Poměry na pstruhových vodách se zhoršují rychleji, než jsme očekávali]. Rybářství, 7: 52-57.

TUFTS, K., HOLDEN, J. and DEMILLE, M. 2015. Benefits arising from sustainable use of North America's fishery resources: economic and conservation impacts of recreational angling. African International Journal of Environmental Studies, 72(5): 850-868.

WALDNER, K., BECHTER, T., AUER, S., BORGWARDT, F., EL-MATBOULI, M. and UNFER, G. 2020. A brown trout (Salmo trutta) population faces devastating consequences due to proliferative kidney disease and temperature increase: A case study from Austria. Ecology of Freshwater Fish, 29(3): 456-476.

ZAPLETAL, T. and ŠPAČEK, J. 2018. Food competition between salmonids in a polluted submountain stream [in Czech: Potravní konkurence lososovitých ryb ve znečištěném podhorském toku]. Opera Corcontica, 55: 95-102.

ZAPLETAL, T. 2020. The exploitation of water streams for trout angling [in Czech: Využití vodních toků pro pstruhový rybolov]. Vodní hospodářství, 2: 4-7.

ZAPLETAL, T. 2020. Organic pollution of streams depends on economic development in Czech Republic [in Czech: Zatížení tekoucích vod organickým znečištěním v závislosti na ekonomickém vývoji v České republice]. VTEI, 4: 26-29.

\section{Contact information}

Tomáš Zapletal: slapansky@ivb.cz (corresponding author)

Jan Grmela: jencekg@seznam.cz 
